\title{
Survival, Growth and Establishment of Grafted Pawpaws in Upstate New York
}

\author{
Ian A. Merwin, ${ }^{1}$ Rachel Byard, ${ }^{2}$ and Kirk W. Pomper ${ }^{3}$
}

Additional indeX words. Asimina triloba, tree-tubes, pollination

\begin{abstract}
SUMmARY. A pawpaw regional variety trial (PRVT) was established at Cornell University, Ithaca, N.Y. in Apr. 1999 consisting of 28 commercially available pawpaw (Asimina triloba) varieties or advanced selections from the PawPaw Foundation (PPF; Frankfort, Ky.). Eight replicate trees of each selection, grafted onto seedling rootstocks, were planted in a randomized block design. The first two winters at the test planting site were unusually mild for the Finger Lakes region, with the lowest recorded temperatures above $-16{ }^{\circ} \mathrm{C}$ $\left(3.2^{\circ} \mathrm{F}\right)$. Despite these mild winters, there was extensive winter mortality of some pawpaw varieties. Survival rates were $>75 \%$ for 11 varieties, and were $<40 \%$ for five other varieties. Poor establishment of grafted clonal pawpaws and insufficient pollination or fertilization of established pawpaws were important limitations of successful commercialization of this new fruit crop under conditions typical of upstate New York. Open mesh black plastic trunk guards provided adequate shade and protection for newly planted pawpaws, whereas translucent plastic tree-tubes caused heat stress and scorching of the young trees.
\end{abstract}

$\mathrm{T}$

he Finger Lakes and Lake Ontario regions of upstate New York are at the northern limits of the original range for pawpaw in North America (Darrow 1975; Kral

1960). When the national PRVT was organized in 1994, we offered to establish a test planting on a Cornell research farm in Lansing, N.Y., to evaluate survival and adaptation of promising pawpaw varieties in a cool humid fruit-growing region (Layne, 1996; Pomper et al., 1999).

\section{Establishment of the variety trial}

In April 1999, we received and planted 224 recently grafted pawpaws from the PRVT nursery in Oregon, representing eight replications of 28 varieties. This planting included 10 commercially available varieties and 18 advanced selections from PPF grafted onto seedling rootstocks. Named varieties in the trial included: Middletown (selected in Ohio), Mitchell (Illinois), NC-1 (Ontario, Canada), Overleese (Indiana), PA-Golden \#1 (New York), Sunflower (Kansas), Taylor (Michigan), Taytwo (Michigan), Wells (Indiana), and Wilson (Kentucky). The other 18 clones that we evaluated were selected from PPF orchards by R. Neal Peterson at the University of Maryland Experiment Stations at Queenstown and Keedysville, $\mathrm{Md}$.

The PPF advanced selections were selected based on superior traits including fruit size and taste, high flesh-to-seed ratio, resistance to pests and diseases, and overall productivity on a year-toyear basis.

\footnotetext{
${ }^{1}$ Associate professor, 118 Plant Science Bldg. Dept. of Horticulture, Cornell University, Ithaca, NY 14853 5908.

${ }^{2}$ Research assistant, 118 Plant Science Bldg. Dept. of Horticulture, Cornell University, Ithaca, NY 14853-5908.

${ }^{3}$ Principal investigator of horticulture and curator, USDA National Clonal Germplasm Repository for Asimina species., Atwood Research Facility, Kentucky State University, Frankfort, KY 400601-2355.
} 
Table 1. Average vigor of shoot growth and percent survival of 28 clonally propagated pawpaw varieties in an upstate New York planting during 1999-2001.

\begin{tabular}{|c|c|c|}
\hline Variety & $\begin{array}{c}\text { Growth } \\
\text { vigor }^{\mathrm{z}}\end{array}$ & $\begin{array}{c}\text { Survival } \\
(\%)\end{array}$ \\
\hline $3-21$ & 0.2 & 12.5 \\
\hline $4-2$ & 0.6 & 25.0 \\
\hline $11-13$ & 1.0 & 37.5 \\
\hline Overleese & 1.0 & 37.5 \\
\hline $9-47$ & 1.3 & 37.5 \\
\hline Wilson & 1.3 & 50.0 \\
\hline $1-7-2$ & 1.4 & 50.0 \\
\hline $10-35$ & 1.4 & 62.5 \\
\hline Wells & 1.4 & 50.0 \\
\hline $2-10$ & 1.5 & 50.0 \\
\hline $7-90$ & 1.6 & 62.5 \\
\hline Middletown & 1.6 & 62.5 \\
\hline $9-58$ & 1.8 & 50.0 \\
\hline Mitchell & 1.9 & 62.5 \\
\hline Taylor & 1.9 & 62.5 \\
\hline $1-68$ & 2.0 & 75.0 \\
\hline 5-5 & 2.1 & 75.0 \\
\hline $1-23$ & 2.2 & 75.0 \\
\hline $11-5$ & 2.4 & 75.0 \\
\hline $3-11$ & 2.4 & 62.5 \\
\hline $8-20$ & 2.4 & 87.5 \\
\hline PA-Golden & 2.4 & 62.5 \\
\hline Sunflower & 2.4 & 75.0 \\
\hline $8-58$ & 2.8 & 75.0 \\
\hline NC-1 & 2.9 & 100.0 \\
\hline $2-54$ & 3.2 & 100.0 \\
\hline $1-7-1$ & 3.3 & 75.0 \\
\hline Taytwo & 3.3 & 100.0 \\
\hline
\end{tabular}

Trees were planted in an orchard site that should be well suited for this species. The glacial till soil was a gravelly silt loam in texture with $\mathrm{pH}$ ranging from 5.6 to 6.2. The site sloped about $8 \%$ toward the southwest and was near the deepest part of Cayuga Lake, which remains unfrozen in winter and creates a strong lake effect that moderates mid-winter cold temperatures. Trickle irrigation was installed at planting, and weed control in the tree row was provided with May and July applications of glyphosate and paraquat postemergence herbicides.

In accordance with protocols for the PRVT, shortly after planting we installed translucent double-walled polyethylene tree-tubes around each pawpaw, securing them with bamboo stakes. During a week of unusually warm days in July 1999 when afternoon temperatures exceeded $36^{\circ} \mathrm{C}\left(96.8^{\circ} \mathrm{F}\right)$, most of the foliage within tubes became heat-stressed and dessicated. Tubes were removed promptly, and the young trees then grew replace-

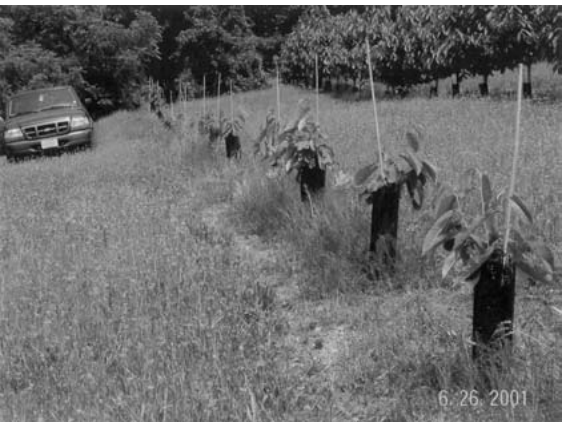

Fig. 1. View of one block (center of picture) in a Lansing, N.Y., pawpaw regional variety trial during its third year of growth in late June 2001. Each tree represents one replicate for each of the 28 varieties. The adjacent row (upper right hand side of picture) of much larger seedling pawpaws was planted 2 years earlier, and has established very successfully with excellent tree growth and negligible winter mortality. Open black plastic mesh cylinders were placed around each grafted tree (left-center of figure) after heat stress damaged foliage within the initially used translucent plastic tree-tubes.

ment leaves. We subsequently replaced the tree tubes with $45-\mathrm{cm}$-high (17.7inch) black polyethylene open mesh cylinders (OESCO Inc., Conway, Mass.) often used to protect young fruit trees from meadow voles (Microtus spp.) in the northeastern U.S. These open mesh cylinders provide a semi-shaded environment similar to the natural understory conditions where pawpaw seedlings and root suckers thrive, and we recommend that others evaluate them as an alternative to the more expensive tree-tubes for promoting establishment of newly planted trees.

\section{Variety survival rates}

The first two winters at our test planting site were unusually mild for the Finger Lakes region, with the lowest recorded temperatures above $-16^{\circ} \mathrm{C}$. Despite these mild winters, there was extensive winter mortality of some pawpaw varieties. Cumulative tree survival rates were $>75 \%$ for 11 varieties, and were $<40 \%$ for five other varieties (Table 1). We also rated tree-growth vigor, which differed substantially among varieties $(P=0.02)$ and was positively correlated with survival rates (Table 1). We attributed the poor survival of some varieties in our test planting to mid-summer heat stress and damaged foliage (as described above), to intrinsic varietal differences, or to potential incompatibilities among scions and seedling rootstocks. We did not observe the putative fungal blight that has been reported at the source nursery and at some of the other PRVT sites around the U.S. (Postman et al., 2003).

By coincidence, our test planting was adjacent to a row of 50 seedling pawpaws planted in Apr. 1998 and maintained similarly to the PRVT except that open mesh guards were used instead of tree tubes. The growth and survival of these 50 seedlings has been excellent in comparison with the PRVT planting (right vs. left hand sides of Fig. 1 , respectively), demonstrating that site conditions were not the cause of the high mortality and low vigor observed in many of the grafted pawpaws.

The main problem observed in our seedling pawpaw planting has been very poor fertilization or viability of flowers. These seedling trees (and a few of our grafted varieties) have flowered profusely during recent springs, but each year only a few flowers have produced viable fruit. We speculate that lack of suitable pollen vectors is the cause of this poor fruit set because observations during bloom revealed little or no insect activity in the pawpaw flowers. Insect pollinator activity (primarily hymenopterans and dipterans) in adjacent pome and stonefruit plantings has been abundant during bloom every year, so there has been no lack of potential pollen vectors.

We conclude that poor establishment of grafted clonal pawpaws, and insufficient pollination or fertilization of established pawpaws may be important limitations of the successful commercialization of this new fruit crop under conditions typical of upstate New York.

\section{Literature cited}

Darrow, G.M. 1975. Minor temperate fruits, $p$ 276-277. In: J. Janick and J.N. Moore (eds.). Advances in fruit breeding. Purdue Univ. Press, West Lafayette, Ind

Kral, R. 1960. A revision of Asimina and Deeringothamnus (Annonaceae). Brittonia 12: 233-278.

Layne, D.R. 1996. The pawpaw [Asimina triloba (L.) Dunal.]: A new fruit crop for Kentucky and the United States. HortScience 31:777-784.

Pomper, K.W., D.R. Layne, and R.N. Peterson. 1999. The pawpaw regional variety trial, p. 353 357. In J. Janick (ed.). Perspectives on new crops and new uses. ASHS Press, Alex., Va.

Postman, J. D., K. E. Hummer, and K. W. Pomper. 2003. Vascular decline in the Oregon pawpaw regional variety trial. HortTechnology $13(3): 418-420$.

Hortlechnology • July-September 2003 13(3) 